\title{
The American role in the Anti-Soviet Afghan War (1977- 1980)
}

Salam Fadhil Hassoon ${ }^{1}$, Naeem Abed Joudah ${ }^{2 *}$

${ }^{1,2^{*}}$ Faculty, Department of History, College of Education for Human Sciences, University of Kerbala, Iraq. Email: ${ }^{1}$ salam.f@uokerbala.edu.iq, ${ }^{2 *}$ naeem.a@uokerbala.edu.iq

\section{Keywords}

Afghan Jihadists, Soviet Invasion, Carter's Administration, Afghan Government, American Aids.

\section{Article History}

Received on $20^{\text {th }}$ July 2021

Accepted on $31^{\text {st }}$ August 2021

Published on $8^{\text {th }}$ September 2021

\section{Cite this article}

Hassoon, S. F., \& Joudah, N. A. (2021). The American role in the Anti-Soviet Afghan War (1977- 1980). Humanities \& Social Sciences Reviews, 9(5), 23-27.

https://doi.org/10.18510/hssr.2021.954

Copyright @Author

Publishing License

This work is licensed under a Creative Commons Attribution-Share Alike 4.0 International License

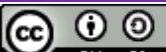

\section{Abstract}

Purpose of the study: This study aims to discuss the American role in the antiSoviet Afghan war and disclose the reasons for the Soviet worry about the growth of the fundamentalist terrorist groups inside Afghanistan.

Methodology: This is library-based research work.

Results: The article has come up with some main points on that severe war. One of these was that the American President Jimmy Carter's Doctrine in 1980. Carter's Doctrine could be considered a sort of policy that allows the use of military force in case American interests are exposed to Soviet threats. As a result, the American administration promised to militarily support the Afghan fighters against the Soviet control in Afghanistan. But, at the same time, the Americans failed to realize the ethnic, ideological, social, lingual, and theological structure of the Afghan society.

Application: This study could have many applications in the faculties of politics and the contemporary altogether to teach the ways of public and secret or hidden political relationships between the secular states or so-called superpowers that employed the extremist groups to overwhelm the stable states that do not subdue to the western domination.

Novelty: This study explores the incorrect claim of the superpowers in general and of the United States of America in particular of the theory of separation religion and the state, which is often used in the double standard.

\section{INTRODUCTION}

After World War II, especially after the advent of the containment policy, the United States tried to block the influence of Soviet influence in Western Europe, the Middle East, and many countries in Asia and Latin America, which was not easy. After 1954, the Soviet Union supported non-developing countries and some countries that were under European imperialist influence, making it a close ally of most Western countries, especially as it promoted further economic assistance to these countries.

The United States and other European countries tried to break this chain of support by trying to create conditions that would cost the Soviet Union its reputation as a friend of suppressed countries. The Soviet occupation of Afghanistan gave the United States and the Western world a golden opportunity, which was largely exploited. This war was used to destroy the "Empire of Evil" and create tension and resentment against the Soviet Union throughout the world, especially in countries that previously supported it.

After the communist revolution in Kabul, Washington policymakers had no clear agenda on dealing with the situation in Afghanistan. But the Soviet invasion of Afghanistan allowed the United States to wage Proxy war in the areas of influence of the Soviet Union. Our study tracked the prefaces of the Soviet invasion, and the role played by President Jimmy Carter's administration in supporting the Afghan mujahideen militarily, technically, and materially while the Americans did not talk about getting the Soviet forces out of Afghanistan or defeating them, and if that's what they sought to achieve (Eizenstat, 2018). Carter's Doctrine could be considered a policy that allows military force if American interests are exposed to Soviet threats and the American administration promised to militarily support the Afghan fighters against the Soviet control in Afghanistan.

Moreover, the Government of the United States took many other procedures as severing the commercial relations with the Soviet Union and declaring a ban on exporting wheat to it. But they failed to realize the ethnic, ideological, social, lingual, and theological structure of the Afghan society. Hence, American politics could not understand the demographic nature of the Afghan community and thought that when the holy war was over, the holy warriors would diminish. The Afghan society could return to its civilian character.

\section{Research Questions}

The aims of this article are incarnated in many questions: Was the synthesis of the American intervention in the AfghanSoviet war based on an essence of doctrinal war, or was it just a struggle of political interests? If the United States of America is regarded as a secular state, then why was it on the side of the Afghan extremist Jahidists holy warriors? And finally, how could the United States of America direct that war and used it as a means to weaken and paralyze the Soviet Union? 


\section{Objectives of this study}

This research is planned to disclose the reasons for the Soviet worry about the growth of the fundamentalist terrorist groups inside Afghanistan. Those extremist gangs tried to overthrow the Government of Hafizullah Amin and to establish an Islamic state instead. Indeed, the study aims to reveal the fears of the Soviet Union of that extremist power, for it could provoke about thirty million Muslims inside the Soviet Union who were bordering the Afghan boundaries. In addition, the article sheds light on the American explanation of the Soviet Union aggression as an attempt to penetrate the Middle East and threaten the oil interests of the United States of America in the Persian Gulf.

\section{METHODOLOGY}

This study has benefited from a valuable collection of historical sources, ranging from documents, books, magazines, and television interviews. The documents of the United States Department of Defense's Afghan Foreign Affairs Task Force are perhaps the most important sources of valuable information obtained from the United States Library of Congress and other sources.

Thus, in this study, we try to collect the information from the library centres, and then by analyzing it, we classify the related results.

\section{RESULTS AND DISCUSSION}

President Jimmy Carter linked his foreign policy to the cause of human rights by signing a directive stating that the United States must promote human rights worldwide. Both President Carter and his Secretary of State, strongly expressed those human rights must be the key to the formulation and implementation of American foreign policy (McClellan, 1985). According to Carter and Vance, the study of human rights must permeate bilateral relations with other States in the areas of arms transfers, foreign assistance, and North-South dialogue, and neither of them was interested in understanding or knowing the limits of human rationality concerning the complex nature of human rights. They also ignored the fact that human beings did not have sufficient knowledge about human rights. Moreover, Congress was divided on the issue of human rights between conservatives, who were concerned with human rights violations in communist states, and liberals interested in the conduct of far-right dictatorships (Donald, 1979).

When the Soviet-backed communists came to power in Afghanistan after a revolution on April 27, 1978, the Carter administration's first reaction at the start of the revolution was limited to the human rights issue under the communist regime. The Carter administration continued to assist the United States with Afghanistan. However, Congress had some sentiment to end such programs under section 620 of the Foreign Assistance Act of 1961, which prohibits assistance to any communist state (Holsti, 1982).

\section{President Jimmy Carter's administration and the Soviet invasion}

The United States has provided funds to Afghanistan from 1946 until 1978, estimated at 2.504 million dollars, 80\% of which was the form of economic assistance and financial. However, the murder of American Ambassador Adolph D. by the hands of unknown persons in Kabul on February 14, 1979, other than the position of the United States, although the United States Administration announced a sharp reduction in aid after the killing of Ambassador Dobbs, it did not fully reduce that assistance until August 14, 1979, when President Carter signed the International Development Cooperation Act of 1979. The United States feared that it would lose its minimum impact on Afghanistan by antagonizing the Afghan People's Democratic Party and its regime. It also avoided publicly criticizing the Afghan government or calling it communist, which would have forced the Carter administration to act by the Foreign Assistance Act. Any additional assistance to Afghanistan unless the President states to Congress that the Afghan Government has formally apologized acknowledged the responsibility for Ambassador Dobbs' murder, and agreed to provide adequate protection to all United States Government personnel in Afghanistan (Leffler, 2018).

President Carter's administration was concerned and interested in the Afghan government's orientation in domestic and foreign policy, its consequences, and its effects in the region. After the death of the American ambassador, the United States focused heavily on the decision of President Carter and his national security adviser, Zbigniew Brezinski. Zbigniew Brzezinski helped the "Afghan mujahideen" before the Soviet invasion of Afghanistan, hoping that the Soviet Union would be involved in military intervention there, and launched various initiatives to engage the Soviet Union, militarily in Afghanistan. Assistance programs were the basis of United States covert and open operations in Afghanistan and in successive ways to implicate the Soviet Union there. President Carter's National Security Adviser, Zbigniew Breginsky, emphasized this point in an interview with French Publicist Le Nouvel in which he responded to his question about the timing of United States assistance to the "Afghan mujahideen" as follows: "On July 3, 1979, President Carter signed the First Secret Assistance Directive to opponents of the pro-Soviet regime in Kabul. On that day, I wrote a note to the president explaining that this assistance would prompt the Soviets to intervene militarily when we did not push them but increased the likelihood of their intervention." That covert operation was an excellent idea to set the Russians in the Afghan trap. Brezinski was also asked about the consequences of overt and unspoken U.S. assistance to "Afghan mujahideen" and asked whether he regretted supporting Islamic fundamentalism or not?... What is the most important for the history of the world? The Taliban or the collapse of the Soviet empire is? He pointed out that the main goal for the Americans was to weaken Soviet influence in Asia (Holsti, 1982). 
The United States did not expect the Soviet Union to invade Afghanistan in the foreseeable future, but as soon as the invasion occurred on December 27, 1979, U.S. policymakers were forced to reassess the U.S. role in world affairs before the Soviet invasion, since it had not intervened in world affairs and had been somewhat neutral since its defeat in the Vietnam War. Involvement in any foreign war has become contingent on the exposure of vital American interests. Global commitments have been reduced under the Nixon Doctrine, which emphasizes the responsibility of United States allies to provide their security and regional responsibilities to provide security. This trend has continued throughout the Ford and Carter administrations (Arka, 2013).

The Carter administration emphasized a policy of avoiding military intervention abroad. Proponents of a nonintervention policy may understand better when examining the records of human rights advocacy that have been full of incidents that have caused great embarrassment to the United States. In Cambodia, for example, Paul Botti killed nearly 2 million people, while President Carter's only response was to condemn such acts, while Cambodians were tortured and not allowed to travel or leave the country, and the United States took no action against him. In South Africa, the United States failed to implement economic sanctions fully; in Uganda, the U.S. boycott of Ugandan coffee faced a threat of retaliation against 150 Americans living in Uganda. China's disregard and indifference to human rights in Xinjiang or Chinese Turkestan and Tibet were met with hostility by the Americans (McClellan, 1985). But the fall of the Shah in Iran at the beginning of 1979 and the Soviet invasion of Afghanistan forced the United States to reframe its priorities in the region, where its strategic interests were in imminent danger. The weakening of oil resources in the Middle East, vital to the Western world, exposed the geopolitical shortcomings of the United States, and the invasion of Afghanistan accelerated the process of retreating from deflation towards strengthening some form of re-imposition of hegemony. The invasion seemed to challenge the United States to create a policy based on a new national consensus that required the necessary military force to support any role it was decided to play (Rennack \& Chesser, 2011).

At this point, the decision-making process moved from a state of reservation and caution to a review of decision-making, in other words, a change in the "step by step" policy to ensure and promote the cause of human rights, paying more attention to the concepts affected by recent and immediate events. President Carter and Brezinski did not have a direct policy and agenda of the communist regime in Kabul and the Soviet intervention in Afghanistan; they were trying to sort out the contradictions in their policy towards the developments in Afghanistan; on the one hand, they took several methods to implicate the Soviet Union in Afghanistan. On the other hand, the United States feared that the Soviet Union would be there permanently, though that would mean approaching the oil fields in the Middle East.

Policymakers in Washington believed that the Soviet Union could exert influence and control over oil supplies in the Middle East and perhaps control waterways in key regions of the region. In this critical situation, the United States tried to create a balance in the equality of power and began to cooperate closely with Pakistan again in South Asia; Pakistan was the only Islamic State of the United States that could guarantee Washington the protection of its interests in the region. To ensure that the Soviet Union did not extend its influence south and east of the Durand Line, Breginsky took a trip to Islamabad at the beginning of February 1980 to meet with Pakistani President General Zia-ul-Haq, and to discuss the American-Pakistani strategy to stop the Soviet Union's expansion in Pakistan. The United States had promised Pakistan 100 million dollars in support of the military and 100 million in economic assistance, but Pakistan rejected this offer as insufficient, and later in 1980, the United States agreed to provide (200) million dollars to Pakistan for the first year with a total of two billion dollars in five years a fund was established for this purpose. This fund was to support Japan with 128 million dollars and Britain with 38 million dollars (Lowenstein, 2016).

In his State of the Union address in January 1980, President Jimmy Carter took the first step to change the direction of U.S. foreign policy from non-intervention due to the suffering of the Vietnam syndrome' to a more intrusive policy of intervention, declaring that Soviet military aggression represents a serious challenge to the United States of America and all countries of the world and that any attempt by any external force to control the Persian Gulf area would be considered an attack on the vital interests of the United States They will be repulsed by any means necessary, including military force (Eizenstat, 2018). The most practical, least expensive, and most beneficial action for the United States at the time was to help the "Afghan mujahideen" with minimal but far less financial costs than to confront the Soviet Union in a Middle Eastern country. Therefore, the United States has channelled arms, ammunition, and money to the Afghan mujahideen through Saudi Arabia and Pakistan, especially since Saudi support was not limited to sending military assistance but rather to provide financial support. For all the assistance provided by the United States, Saudi Arabia has been doing the same. Prince Turki al-Faisal confirmed this point in an interview with BBC News with Elisabeth Francois on January 21, 2002. In response to a question, Al-Faisal said, "When I was Director of Intelligence, I was responsible for supporting the mujahideen. This was a tripartite agreement between the Kingdom, the United States, and Pakistan." President Carter sent weapons to the Afghan resistance after the Soviet invasion on 27 December 1979. But strictly speaking, the United States began to help the resistance subtly almost a year ago; although the United States was convinced that the Afghans would not defeat the Soviets, yet it was willing to fight the Soviet Union in Afghanistan until the last Afghans (Justin, 1918).

The United States wanted to create a non-healing wound for the Soviet Union parallel to the American wound in Vietnam and, as a result, created Soviet Vietnam in Afghanistan. The United States has also helped various factions and "mujahideen groups" to destabilize the already unknown Communist regime. This assistance aimed not only to wage a proxy war against the Soviet-backed Communist government itself but also to put Afghanistan under its sphere of 
influence. To achieve this, money and weapons were needed to move this plan forward. So, the first weapons -mainly of the type, 303 Anfield rifles -appeared in Pakistan on 10 January 1980, 14 days after the Soviet invasion (Eizenstat, $\underline{2018) \text {. }}$

The United States Central Intelligence Agency (CIA) also supplied Afghan fighters with weapons from Egypt with funds destined for Saudi Arabia. By 1983, the CIA purchased a total of 10 thousand tons of assault rifles, grenade launchers, mines, and anti-aircraft SA-7, mostly from China has also been moved hundreds of millions of dollars of sophisticated weapons to Pakistan to bring her to "the Afghan mujahideen". CIA agents closely monitored military operations and, in some cases, were directly involved in the escalation of the war.

Military and economic assistance to the mujahideen of Afghanistan and the CIA in the Afghan jihad increased after Ronald Reagan became president of the United States. President Reagan's foreign policy towards Afghanistan and his involvement with the Afghan mujahideen were greatly influenced by his strong anti-communist stance and belief in fighting the "evil empire." Ronald's perceptions, values, preferences, and goals have gained "critical importance." According to President Reagan, communist States were evil entities that violated fundamental human rights and the freedom of their people, and that deserved to be contained. He declared on many occasions that the United States would not stop fighting communism at a time when Soviet imperialism was spreading around the world. (Genovese, 2009)

The war in Afghanistan finally led to the Soviet withdrawal from Afghanistan, the weakening of the Soviet economy and the exhaustion of the army, and the end of the Cold War also the collapse of the Soviet Union. Although "Afghan jihad" was the important factor that triggered these changes. However, other factors have contributed in one way or another to these facts.

\section{CONCLUSION}

The Soviet invasion of Afghanistan presented security and economic challenges to the United States. After the Soviet invasion of Afghanistan, the United States had no clear strategy for how to respond to the invasion. When Ghulam Farooq Azzam visited the United States, a prominent member of the "Najat Mili" front and the Afghan Minister of Education during Burhanuddin Rabbani's era after the Soviet invasion and met officials in Washington, he concluded from his meetings that the United States was concerned that the Soviet Union would not stop in Afghanistan. Perhaps he will continue his expansionist policy towards Pakistan, and it did not hide its concern about its interests in the region, but it did not find the appropriate way to address this issue. All they knew was that the Afghans were willing to fight the Russians and that the Americans were willing to help them. At the end of the 1970s and throughout the 1980s, American policymakers underestimated their future uncertainty when they were making policy choices about Afghanistan. They believed that they had more control over the events than they already had.

By providing financial and military support to the Afghan mujahideen, they would be able to control the mujahideen either directly or through Pakistan and reduce any potential problems that might arise due to their financial and military assistance. At the same time, they failed to understand the "ethnic and linguistic divide, social structure, and religious ideology of Afghans," which are important to understand Afghanistan and its people. Besides, policymakers in Washington could not look outside the scope of their experience and wanted to see things positively. Also, Washington policymakers were unable to look beyond their experience and wanted to see things positively. Their optimism misled their perceptions and thinking, which simplified the complex nature of Afghan Jihad. In other words, the United States believed that if they provided money and weapons to the Afghan mujahideen, they would fight the Soviet Union and the communist regime, causing the regime to collapse in Kabul, and then normalize things, but After the Soviet withdrawal and the collapse of the communist regime, it ended in a civil war. This failure may be due to the misunderstanding by the United States of the social and religious structure of the country, as well as to Pakistan's deliberate attempts to mislead the American vision that has in one way or another influenced the direction of American foreign policy in the face of developments in Afghanistan.

\section{LIMITATION AND STUDY FORWARD}

This study is limited to discuss the American intervention in the Anti-Soviet Afghan war. For further studies, it may be helpful to do the same research about other countries.

\section{AUTHORS CONTRIBUTION}

Salam Fadhil Hassoon Alsarhan has contributed to data gathering, note-taking, library research, document preparation, and writing the preliminary framework of the article. Naeem Abed Joudah read the suggestions for improving the quality of the article, revising it, and contributed to the section on the identification of the properties of the tribes and specialized translation and English literature edition.

\section{REFERENCES}

1. Arka, B. (2013). Durand Line: history Legality and Future. Occasional Paper, Vivekananda International Foundation, New Delhi.

2. Bell, W. G. (1981). Secretaries of War and Secretaries of the Army. Washington, D.C.: Center of Military History. 
3. Britannica, T. Editors of Encyclopaedia (2020, May 11). Soviet invasion of Afghanistan. Encyclopedia Britannica. https://www.britannica.com/event/Soviet-invasion-of-Afghanistan

4. Brzezinski, Z. K. (1983). Power and Principle: Memoirs of the National Security Advisor 1977-1981. New York: Farrar, Straus and Giroux.

5. Carter J. (1982). Keeping Faith: Memoirs of a President. Fayetteville: University of Arkansas Press.

6. Donald, P. (1979). Lecher, Hurrian Rights and American Foreign Policy. Norte Dale, Indian: University of Norte Damen Press.

7. Eizenstat, S. E. (2018). President Carter: The White House Years. Thomas Dunne Books.

8. Gelb, L. H. (1980, April 29). Vance-Torn by Ideals and by Loyalty to Carter. The New York Times

9. Genovese, M. A. (2009). Encyclopedia of the American Presidency. Facts on File.

10. Holsti, K. (1982). Why Nations Realign: Foreign Policy Restructuring in the Postwar World. London: UK: George Allen \& Unwin Publishers, Ltd., PP: 208-219.

11. Jordan, H. (1982). Crisis: The Last Year of the Carter Presidency. New York: Putnam.

12. Justin, V. (1918). American Grand Strategist, Translate Catherin Porter. New York: Harvard University, PP: 119-137.

13. Kaufman, S. (2008). Plans Unraveled: The Foreign Policy of the Carter Administration. De Kalb: Northern Illinois Press.

14. Leffler, M. P. (2018), Ronald Reagan, and The Cold War: What Mattered Most. Taxes national Security Review, 1(3), 77-89.

15. Lowenstein, U. J. (2016). Foreign policy and the Soviet-Afghan War: A Revisionist History. Yale University Press, PP: 53-62.

16. McLellan, D. S. (1985). Cyrus Vance (American Secretaries of State and Their Diplomacy, number 20.). Totowa, N.J.: Rowman and Allanheld.

17. Newman, W. W. (2003), Managing National Security Policy: The President and the Process. Pittsburgh: University of Pittsburgh Press.

18. Rennack, D. E. \& Chesser S. G. (2011). Foreign Assistance Act of 1961: Authorizations and Corresponding Appropriations. Congressional Research Service, Washington.

19. Smith, G. (1986). Morality, Reason and Power: American Diplomacy in the Carter Years. New York: Hill and Wang.

20. Vance, C. R. (1983). Hard Choices. New York: Simon and Schuster. 